\title{
SIMPLIFICATION AND VERIFICATION OF DYNAMIC EQUATIONS OF MOVEMENT OF AN AUTONOMUS UNDERWATER VEHICLE
}

Urgency of the research. Currently, most machines go through computer modelling and simulation phase in their development cycle. The ability to formulate simple yet effective models helps to both decrease development cost and time.

Target setting. Today many tasks are being accomplished by robots whether mobile robots or industrial robots. To simulate the behaviour of these robots a dynamic model is needed. These models can be very complex and the parameters to fill all the equations can be difficult to find, therefore simplifications need to be implemented and verified so that the models are still accurate.

Actual scientific researches and issues analysis. $A$ basic step in the development of new products is the simulation and modeling phase. Development of a computer model prior to development of a physical prototype saves time and resources. Unfortunately, some models can be very complex and require parameters only acquirable from tests on physical systems. That is why often these models need to be heavily simplified which can lead to imprecise results. Often, verification of the model is needed. One of such systems is the dynamic model of an Autonomous underwater vehicle (AUV).

Uninvestigated parts of general matters defining. This article focuses on verification of a highly simplified dynamic simulation model of AUV.

The research objective. The aim of these research was to model a simplified dynamic model of an AUV moving through fluid with nonnegligible viscous properties and verifie the model by comparing simulation results with experimental results obtained by testing on the real AUV.

The statement of basic materials. The analysis consists of an attempt to summarise the possible ways to simplify a general dynamic equation for movement of an AUV in a fluid with nonnegligible viscous properties and showing, that even such simplified model stays usable and bring with it reduction in complexity.

Conclusions. This article shows the basic dynamic equations for describing the movement of a general AUV in a fluid with nonnegligible viscous properties and the possible simplification of this equation in regard to a specific construction of a real world AUV. The results gathered from the simulation model are then compared to experimental results performed on the physical AUV with the conclusion, that both datasets are matching within reasonable margins. This article serves as a good reminder of the importance and benefits of well establishing simplifications in a model of a real-life system.

Keywords: AUV; dynamics; simulation.

Fig.: 7. References: 7.

Introduction. The development of complex machines is an expensive and time-consuming process. The development of well build, reliable, but simple models whether it be $3 \mathrm{~d}$, simulation or mathematical models can be a major factor in successful development of a machine.

This aspect of development can be very well seen in the process of design and development of an Autonomous underwater vehicle, AUV for short. AUVs are robots able to operate underwater without the aid of an operator. These vehicles are widely used in situations where the use of remote operated underwater vehicles is not practical. Examples of these tasks are autonomous mine sweepers, underwater wreckage or cave inspection, long term seafloor surveys etc. As can be seen, the task and mission times an AUV can be built for varies, and so varies their design. Also, movement underwater is a very specific task, for which an AUV needs to be well designed as a failure underwater could mean the destruction of the vehicle. It is often necessary to develop a reliable model of such a vehicle to understand its behaviour underwater and for the task of developing a control system for it.

Dynamic model of an AUV. In the next chapter, the description of dynamics of an AUV will be presented. Unlike for objects moving with low speed in air, for which often kinematic description is sufficient, for the correct description of movement of an underwater vehicle it is crucial to define the dynamic equations describing its behaviour in a fluid environment. This applies even for low speed movement. The dynamic model of an AUV shown bellow is according to Fossen [2].

$$
M \cdot \dot{v}+C_{(\dot{v})} \cdot v+D_{(v)}+G=\tau_{E}+\tau
$$

$M$ - matrix of inertial forces

$C_{(\dot{v})}$ - matrix of Coriolis and centripetal forces

$D_{(v)}$ - matrix of hydrodynamic dampening

$G$ - Vector of gravitational and buoyancy forces

$\tau_{E}$ - matrix of external forces and momentums

$\tau$ - matrix of motor forces

$v$ - state velocity vector

(C) Мартин Варга, 2019 
TECHNICAL SCIENCES AND TECHNOLOGIES

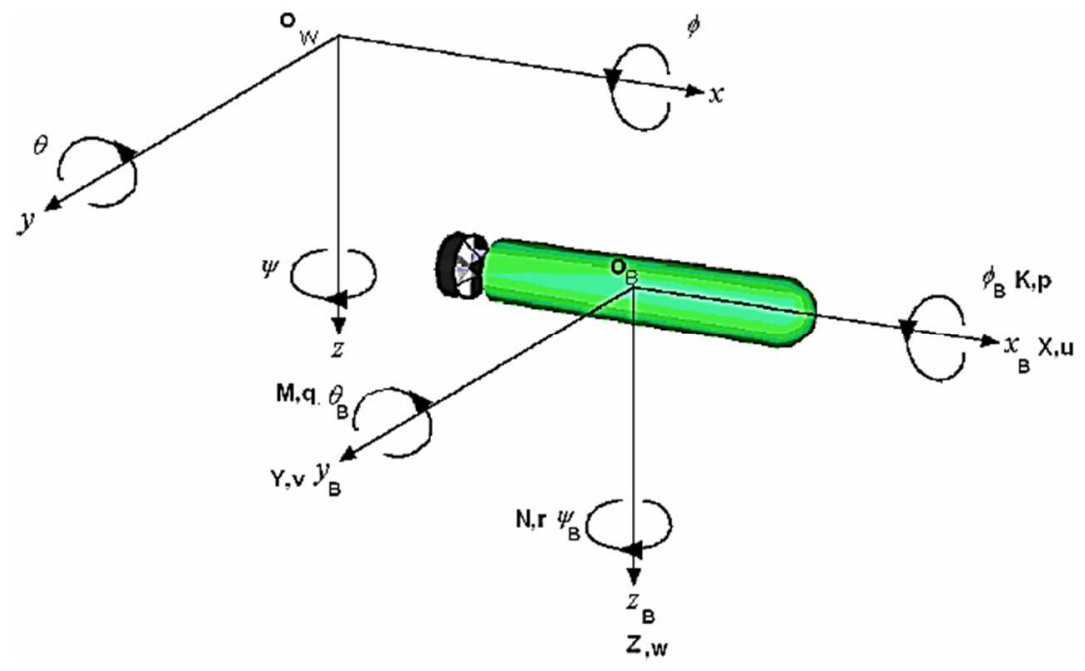

Fig. 1. Coordinate systems of an AUV

It needs to be noted, that all the above-mentioned vectors and matrices are defined in respect to a coordinate system that is rigidly attached to the AUV $\mathrm{B}$ with the $\mathrm{x}$ axis pointing in the direction of the forward movement of the AUV.

The matrix $\mathrm{M}$ consists of the matrix of own internal inertia $M_{R B}$ and the matrix of added (virtual) mass $M_{A}$. The matrix $M_{A}$ is derived from the kinetic energy equation of the flowing fluid that was given to it by the movement of the AUV. The elements of the matrix $M_{A}$ are for a fully submerged vehicle constant and will always have a positive value.

$$
M=M_{R B}+M_{A}
$$

The matrix of Coriolis and centripetal forces is in relation to the matrix of inertia $M$ an therefore also has two elements, $C_{R B(\dot{v})}$ the matrix of Coriolis and centripetal forces due to $M_{R B}$ and $C_{A(\dot{v})}$ the matrix of Coriolis and centripetal forces due to $M_{A}$.

$$
C_{(\dot{v})}=C_{R B(\dot{v})}+C_{A(\dot{v})}
$$

The matrix $D_{(v)}$ consists of multiple elements describing multiple types of dampening.

$$
D_{(v)}=D_{P(v)}+D_{S(v)}+D_{W(v)}+D_{M(v)}
$$

$D_{P(v)}$ - potential dampening due to forced oscillation of fluid;

$D_{S(v)}$ - linear and quadratic friction on the boundary layers of the fluid and vehicle;

$D_{W(v)}$ - wave dampening;

$D_{w(v)}$ - dampening due to vortex shedding.

$G$ describes the effect of the buoyancy force and gravitational force upon the AUV in the coordinate system fixed to the AUV, not in the world coordinate system.

Similar to $G$, the matrix of external forces and momentums describes the effects of external force acting upon the AUV relative to the coordinate system fixed the AUV. These forces represent the effects of underwater currents interacting with the AUV.

Finally, the matrix of motor forces $\tau$ represents the forces of the motors the AUV is equipped with. The composition depends on the construction of the AUV.

$$
\tau=L . U
$$

$U$ - vector of all values of motor forces

$\mathrm{L}-6 \mathrm{xn}$ matrix describing the force effects of matrix $\mathrm{U}$ in coordinate system $\mathrm{B}$

All of the abovementioned matrices are 6x6, representing coupled 6 degrees of freedom for describing general motion of an object in a fluid with nonnegligible viscous properties. 
TECHNICAL SCIENCES AND TECHNOLOGIES

Simplification of the dynamics in respect to a specific design of an AUV. As can be seen, the description of the dynamics of general motion of an object in fluid is complex. They require many parameters that, even though, can be calculated under difficulty, are usually found using tests on real life models. In general, it is not necessary to acquire all the parameters required to describe the full 6 DOFs of an AUV. Depending on the specific design of an AUV, simplifications can be made, under certain assumptions, that decrease the number of parameters that need to be acquired and significantly simplify the final dynamic equations.

One common type of AUV is one of frame construction, equipped with two parallel vertical thrusters to control dive and two forward facing thrusters to provide forward and backward movement as also the ability to differentially steer. One of such AUVs is the MAKO (Fig. 2), an AUV build by Andrev Gonzales and team at UWA (The University of Western Australia) for the purpose of participating in the International Autonomous Underwater Vehicle Competition. For this vehicle, all the necessary tests to specify the needed dynamic constants were done and are known. The complete description of this AUV and the methodology of finding the needed constants can be found in [1].

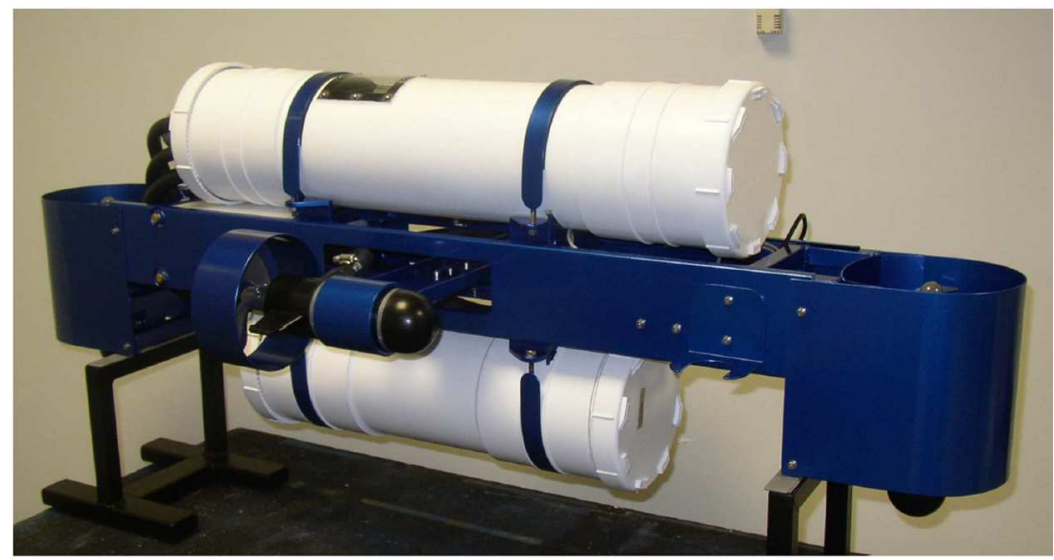

Fig. 2. AUV MAKO

In the following paragraphs, simplification of the dynamic equations for this vehicle will be demonstrated.

For this AUV the following assumptions can be made:

1. AUV moves at slow speed $\left(2 \mathrm{~m} \cdot \mathrm{s}^{-1}\right)$.

2. The vehicle is symmetrical along all three planes of symmetry.

3. Rotation along the $\mathrm{x}$ and $\mathrm{y}$ axis is not being taken into consideration.

4. All degrees of freedom are independent of each other.

The assumption of slow speed in this list is crucial. As can be found in [6], AUVs have an operational speed between $0.5 \mathrm{~m} . \mathrm{s}^{-1}$ and $5 \mathrm{~m} . \mathrm{s}^{-1}$, with most having operational cruising speed of about $1.5 \mathrm{~m} . \mathrm{s}^{-1}$. All the physical tests and modelling done in [1] were done with the assumption of a top speed of $2 \mathrm{~m} . \mathrm{s}^{-1}$, which is close enough to the values stated in [6] to be valid. Thanks to the assumption of low speed, the effects of small asymmetries in the planes of symmetry of the AUV can be neglected. The Coriolis and centripetal forces can be ignored due to assumption of low speed. The matrix of dampening, thanks to the assumption of symmetry and low speed, is reduced only to the matrix of linear and quadratic friction on the boundary layers of the fluid and vehicle. These assumptions effectively decouple all the dynamic equations.

Engineers most often choose to place the centre of buoyancy above the centre of gravity creating passive control of rotation along the $\mathrm{x}$ and $\mathrm{y}$ axis (Fig. 3). This assumption eliminates two Dofs leaving only four: movement along $\mathrm{x}, \mathrm{y}, \mathrm{z}$ and rotation around $\mathrm{z}$. 


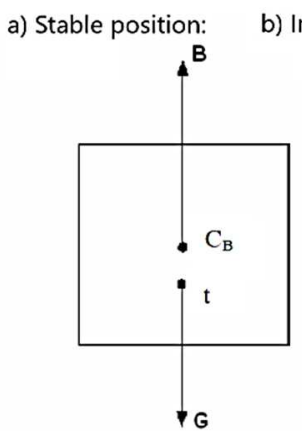

t- centre of gravity

CB- centre of buoyancy

G- vector of gravitational forces

B- vector of buoyancy forces

\section{Fig. 3. Principle of passive stabilization}

After these simplifications are applied, there will be four independent dynamic equations consisting of parameters for every degree of freedom in the general form of:

$$
m_{\vartheta i} \dot{\vartheta}_{i}+d_{\vartheta i} \vartheta_{i}+d_{\vartheta|\vartheta| i} \vartheta_{i}\left|\vartheta_{i}\right|+g_{\vartheta i}=\tau_{\vartheta i}
$$

$m_{\vartheta i}$ - parameter of internal inertial matrix for DOF $\mathrm{i}$;

$d_{\vartheta i}$ - parameter of linear dampening for DOF i;

$d_{\vartheta|\vartheta| i}$ - parameter of quadratic dampening for DOF $\mathrm{i}$;

$g_{\vartheta i}$ - force effects of gravitational and buoyancy on DOF $\mathrm{i}$;

$\tau_{\vartheta i}$ - internal motor force effect for DOF i;

$\vartheta_{i}-$ velocity for DOF $i$.

Simulation of simplified model of AUV and comparison to experimental results.

The above-shown simplified dynamic model ignores many components of the original dynamic model, therefore it is fitting to compare the results given by this model with experimental results, hence validating it.

The necessary parameters for the equations and the experimental results were taken from [1], for the AUV MAKO. The dynamic model was made in the program matlab-simulink (Fig. 4).

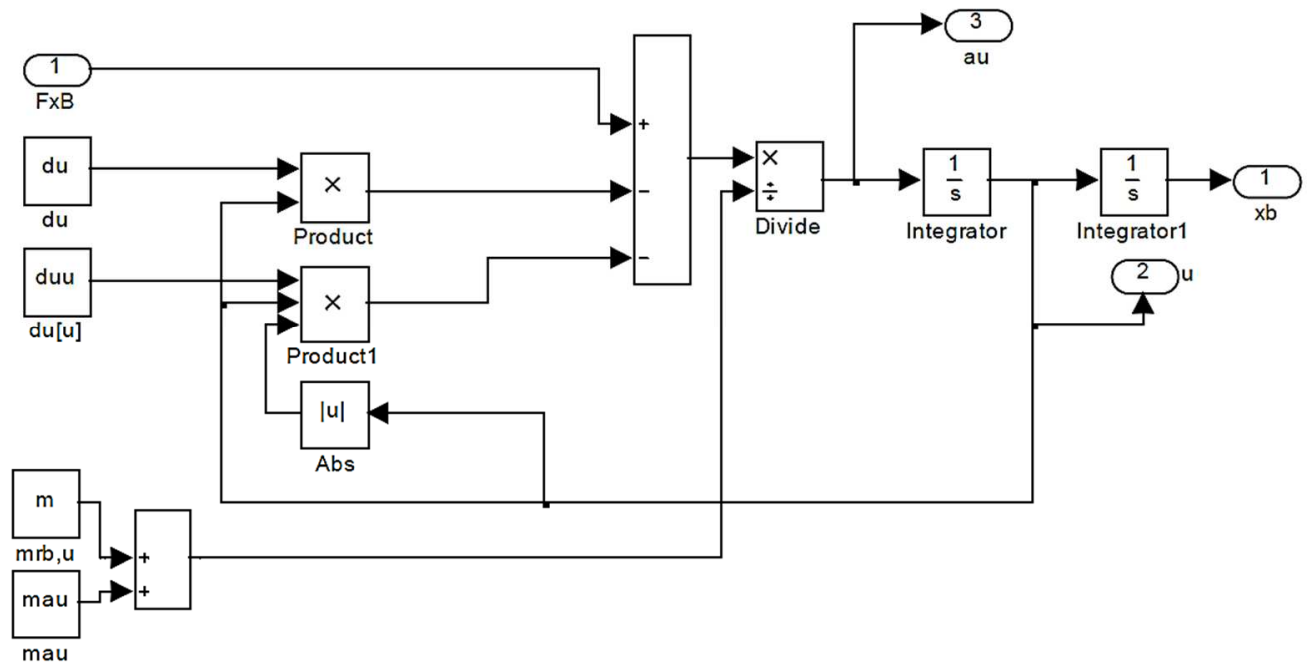

Fig. 4. Dynamic equation for the movement in direction of axis $x$

Below is the comparison between simulation and experiment for movement in direction of $\mathrm{x}, \mathrm{z}$ and rotation around $\mathrm{z}$ is presented. Simulation results come close the experimental results. Some mismatch is the result of measuring errors and limited effects of equation simplification. 
TECHNICAL SCIENCES AND TECHNOLOGIES

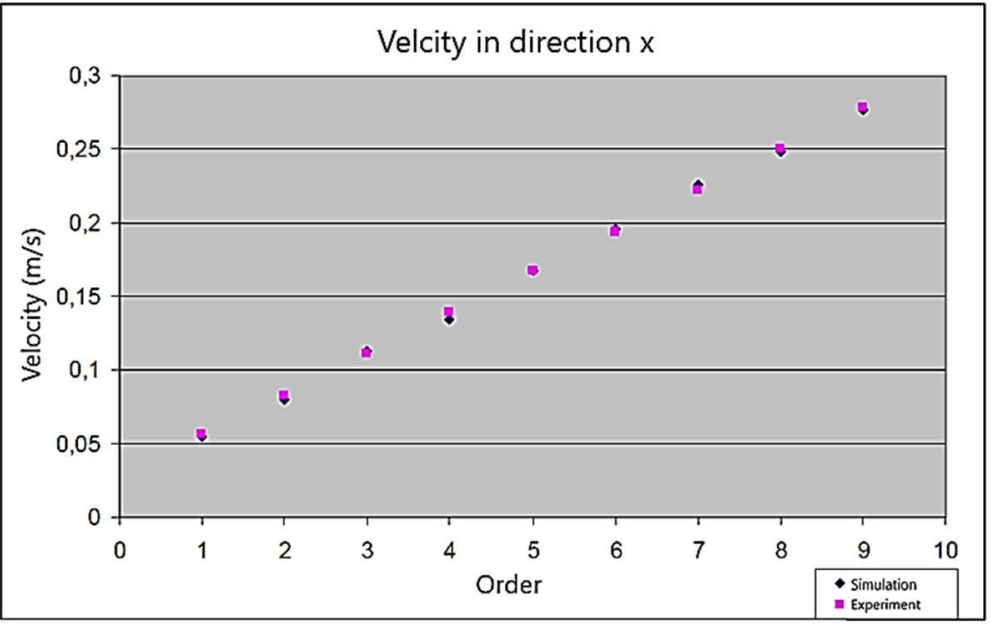

Fig. 5. Comparison between simulation and experiment for movement in direction of $x$

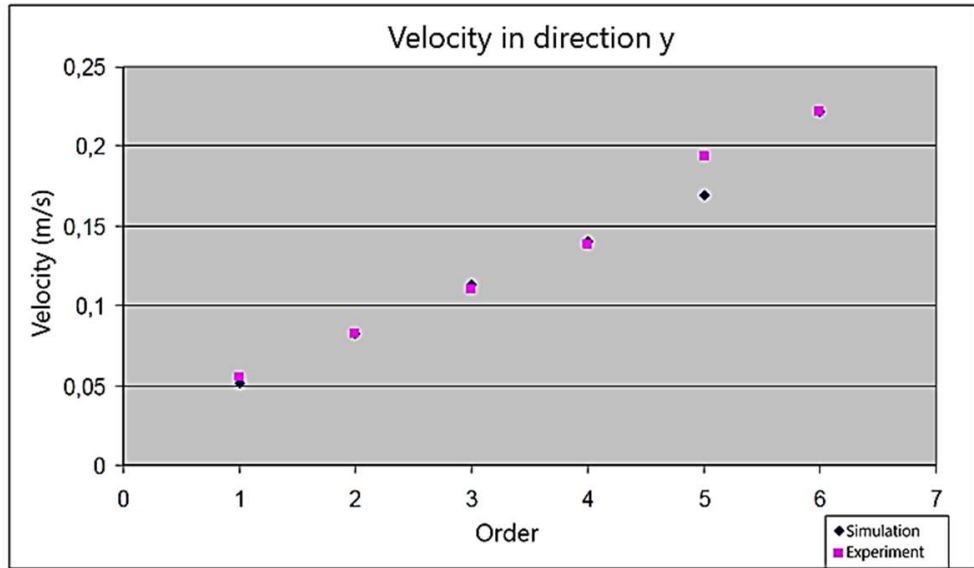

Fig. 6. Comparison between simulation and experiment for movement in direction of $y$

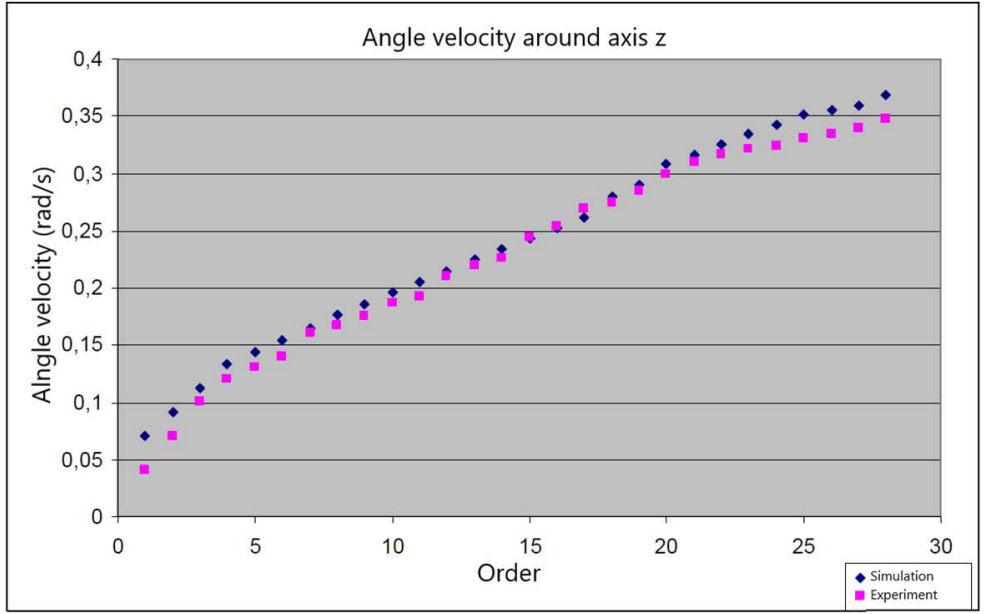

Fig. 7. Comparison between simulation and experiment for rotation around $z$ axis

Conclusions. This article shows the basic dynamic equations for describing the movement of a general AUV in a fluid with nonnegligible viscous properties and the possible simplification of this equation in regard to a specific construction of a real world AUV. As can be seen, even highly simplified models can be reliable and therefore save development time and resources. This is shown on the presented example where the simulation results are compared to experimental results performed on the physical AUV where both datasets are matching within reasonable margins. As this article shows, it is of high importance and benefit to establish sound simplifications in a model of a real-life system. 
Acknowledgements. This research was funded by project VEGA 1/0872/16 and project KEGA 018TUKE-4/2018.

\section{References}

1. Gonzales, L. A. (2004). Design and modeling of an autonomous underwater vehicle. Bachelor of Engineering Honours Thesis. The University of Western Australia, Centre for Intelligent Information Processing Systems/ http://robotics.ee.uwa.edu.au/theses/2004-AUV-Gonzalez.pdf.

2. Thor I. Fossen (1995). Guidance and Control of Ocean Vehicles. John Wiley and Sons United States of America, ISBN 0-471-94113-1.

3. Grepl, R. (2007). Kinematika a dynamika mechatronických systémů. Akademické nakladatelstvý cerm. ISBN 978-80-214-3530-8.

4. P. Ridao, J. RatIle, M. Carreras (2001). Model identification of a low-speed UUV. IFAC Proceedings Volumes (July 2001), 34 (7), 395-400. https://doi.org/10.1016/S1474-6670(17)35114-5.

5. Vervoort, J. H. A. M. (2008). Modeling and Control of an Unmanned Underwater Vehicle. University of Technology Eindhoven Department of Mechanical Engineering Department of Mechanical Engineering Christchurch, New Zealand Eindhoven, The Netherlands. http:/www.mate.tue.nl/ mate/pdfs/10894.pdf.

6. Bellingham, J. (2001). Autonomous underwater vehicles (AUVs), MIT Sea Grant, Cambridge, MA, USA, Academic Press. DOI: 10.1006/rwos.2001.0303.

7. Hoods Hole Oceanographic Institution, Ships \& Technology. [online], [cit. 2011-10-20], Retrieved from: http://www.whoi.edu/page.do?pid=10078.

УДК 629.58

\section{Мартін Варга \\ СПРОЩЕННЯ І ПЕРЕВІРКА ДИНАМІЧНИХ РІВНЯНЬ РУХУ АВТОНОМНОГО ПІДВОДНОГО АВТОМОБІЛЯ}

Актуальність теми досліджсення. В даний час більшість машин проходить етап комп'ютерного моделювання i симулячї в своєму ичклі розробки. Можливість формулювати прості, але ефективні моделі допомагає знизити витрати і час на розробку.

Постановка проблеми. Сьогодні багато завдань виконуються роботами, будь то мобільні роботи або промислові роботи. Для імітачї поведінки ичх роботів необхідна динамічна модель. Ці моделі можуть бути дуже складними, а складові параметри для всіх рівнянь важко знайти, тому потрібно впровадити спрощення та перевірити, щчоб моделі були все-таки точними.

Аналіз останніх досліджень $і$ публікацій. Основним кроком у розробиі нових виробів є створення моделі та етап моделювання. Розробка комп'ютерної моделі попереду розробки фізичного прототипу економить час та ресурси. На жаль, деякі моделі можуть бути дуже складними і вимагають параметрів, які можна отримати лише з випробувань на фізичних системах. Ось чому часто чі моделі потребують значного спрощення, цио може призвести до неточних результатів. Часто потрібна перевірка моделі. Однією з таких систем є динамічна модель автономного підводного автомобіля (АПА).

Виділення недосліджсенх частин загальної проблеми. Ця стаття присвячена верифікації сильно спрощеної моделі динамічного моделювання АПА.

Постановка завдання. Метою ичи досліджень було змоделювати спрощену динамічну модель АПА, щчо рухається через рідину з несуттєвими в'язкими властивостями, і перевірити модель шляхом порівняння результатів моделювання з експериментальними результатами, отриманими при тестуванні на реальному АПА.

Виклад основного матеріалу. Аналіз складасться зі спроби узагальнити можливі способи спрощення загального динамічного рівняння для руху АПА у рідині з несуттєвими в'язкими властивостями та показати, ио навіть така спрошена модель залишається придатною для використання та приводить до зменшення ї̈ складності.

Висновки відповідно до статmі. У иій статті показані основні динамічні рівняння для опису руху загальної АПА у рідині з неглибокими в'язкими властивостями та можливе спрощення иього рівняння, щодо конкретної конструкиії реального АПА. Результати, отримані з імітаційної моделі, потім порівнюються з експериментальними результатами, виконаними на реальному АПА, з висновком, що обидва набори даних збігаються в допустимих межах. Ця стаття служить гарним нагадуванням про важливість та переваги вірно встановленних спрощень для подальшого розрахунку реальних моделей.

Ключові слова: автономний підводний вітомобіль (АПА); динаміка; моделювання.

Рис.: 7. Бібл.: 7.

Martin Varga - PhD student, Technical University of Košice, Faculty of Mechanical Engineering, Institute of Automation, Mechatronics and Robotics, Department of Mechatronics (Park Komenského 8, 04200 Košice).

Мартин Варга - аспірант, Технічний університет Кошице, Факультет механічної інженерії, Інститут автоматики, мехатроніки та робототехніки, кафедра мехатроніки (Park Komenskeho 8, 04200 Košice, Slovak Republic).

E-mail: martin.varga.2@tuke.sk

Varga, M. (2019). Simplification and verification of dynamic equations of movement of an autonomus underwater vehicle. Technical sciences and technologies, 4 (18), 43-48. 